\title{
硫化モリブデン触媒を用いた安息香酸類の 水素一硫化水素による還元
}

\section{小泊 満 生*板 橋 国 夫*}

The Reduction of Benzoic Acids with Hydrogen-Hydrogen

Sulfide in the Presence of $\mathrm{MoS}_{3}$ Catalyst.

Mitsuo Kodomari* and Kunio Itabashi*

Benzoic acids and sulfur were allowed to react under the initial hydrogen pressure $100 \mathrm{~kg} / \mathrm{cm}^{2}$ at $250^{\circ} \mathrm{C}$ in the presence of $\mathrm{MoS}_{3}$. Toluene and a little amount of $\alpha$-toluenethiol were obtained. Similar results were also obtained from substituted benzoic acids, but in the case of benzoic acids containing electron-donating group the corresponding thiols were not obtained, the resulting compounds were mainly products of decarboxylation. In the case of phthalic anhydride, thiophthalide was obtained in good yield under the same reaction conditions. Depending on the conditions, thiophthalic anhydride and $o$-xylene sulfide were obtained in good yield respectively.

概 要

安息香酸とイオウを三硫化モリブデンの存在， $250^{\circ} \mathrm{C}$, 水素初圧 $100 \mathrm{~kg} / \mathrm{cm}^{2}$ で反応させたところ, トルエンと 少量の ロートルエンチオールを得た。アミノ基を有する 置換安息香酸の反応では，チオールは得られず，脱炭酸 生成物が主として得られた。電子吸引性の置換基を有す る場合，脱炭酸はみとめられず，チオールの収率むわず かにすぎなかった。無水フタール酸からは同様条件下で 好収率でチオフタリドが得られたが，条件によりチオ無 水フタール酸, 0 -キシレンスルフィドがそれぞれ好収率 で得られた。

\section{I. 緒言}

さきにドデカン酸の還元チオール化によりドデカンチ オールが好収率で得られることを報告しだ。芳香族カ

* 日本大学理工学部工業化学科

* Department of Industrial Chemistry, Faculty of Science and Engineering, Nihon University
ルボン酸についての還元チオール化反応についてはいま だ知られていない。よって安息香酸および置換安息香酸 について, 硫化モリブテン触媒の存在でイオウと加圧水 素下の反応を行ない, その様相, 置換基の影響などにつ いて検討を加えた。

\section{II. 実 験}

1. 試料安息香酸および置換安息香酸; 試薬一級 品を常法により精製してそれぞれ文献值に一致する融点 を示すものを使用した。チオ無水フタール酸は無水フタ

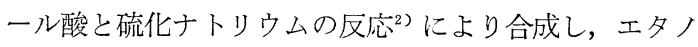
ールで再結晶して融点 $113 \sim 114^{\circ} \mathrm{C}$ の結晶を使用した。

触媒； 三硫化モリブデンの調製は従来どおりチオモ リブデン酸アンモニウムの希硫酸による酸分解によっ だ)。

2. 反応の方法 反応は試料 $(0.1 \mathrm{~mol})$, イオウ $(0.3 \mathrm{~mol})$, 三硫化モリブデン $(1.9 \mathrm{~g})$ ，溶媒 $30 \mathrm{ml}$ を オートクレーブにとり，水素初圧 $100 \mathrm{~kg} / \mathrm{cm}^{2}$ で加熱か きまぜた。反応時間は所定の温度に達してから 100 300 分である。

3. 反応生成物の処理 i. 安息香酸からの生成物 反 
応後のオートクレーブ内容物は口過して不溶物を別け， 溶媒留去後, 蒸留し $110^{\circ} \mathrm{C}$ までの留分 (1) と $70 \sim 75^{\circ} \mathrm{C} /$ $10 \mathrm{mmHg}$ の留分 (2) と残分とに別けた。留分 (2) はチ オールの反応を示し，2,4-ジニトロクロルベンゼンと反 応させ融点 $130^{\circ} \mathrm{C}$ の結晶を得たので $\alpha$ ートルエンチオー ル（その 2,4-ジニトロフェニルチオエーテルの融点の 文献值 ${ }^{4}$ は $130^{\circ} \mathrm{C}$ ) と判明した。残分はエタノールでの 再結晶により得た結晶の融点抒よび安息香酸との混融点 はともに $120 \sim 121^{\circ} \mathrm{C}$ を示したので安息香酸であった。 生成物の定量はガスクロマトグラフの結果によった。

\section{ii. 置換安息香酸加の反応生成物 安息香酸の場} 合とほぼ同様に処理し，チオールの確認定量(5)を行なっ た。生成物蒸留によりそれぞれの留分および残分に別 ち, 誘導体を合成して確認した。カルボン酸の定量はエ ステル化し，ガスクロマトグラフの結果によった。

iii. 無水フタール酸からの反応生成物 反応後の内容 物は口過して, 口液と不溶物に別ち, 不溶物はク口ロホ ルムで抽出し，抽出液は口液と合せる。

これを炭酸ナトリウム水溶液で洗浄した。クロロホル ム溶液はクロロホルムおよび溶媒を留去し, その残分を 得た。残分の一部はガスクロマトグラフにより生成物の 同定，定量を行なった。また残分を減圧蒸留して o-キ シレンスルフィド (bp $105 \sim 110^{\circ} \mathrm{C} / 14 \mathrm{mmHg}$ の留分), チオフタリド ( $\mathrm{bp} 144^{\circ} \mathrm{C} / 17 \mathrm{mmHg}$ ) 単離した。oーキ シレンスルフィドは過酸化水素水により酸化しスルホ ン) $\left(\mathrm{mp} .151 .5^{\circ} \mathrm{C}\right.$, 文献值 $\left.\left.{ }^{6}\right) 151.3 \sim 151.5^{\circ} \mathrm{C}\right)$ として確 認した。をたその赤外吸収スペクトルも文献6) 記載のも のと一致した。

\section{スルホンの元素分析結果}

分析值 C $57.90 \%, \mathrm{H} 4.64 \%$

$\mathrm{C}_{8} \mathrm{H}_{8} \mathrm{O}_{2} \mathrm{~S}$ としての

計算值 C $57.12 \% ， \mathrm{H} 4.79 \%$

チオフタリドはエタノールで再結晶し, 融点 $\left(57^{\circ} \mathrm{C}\right.$, 文献值 $\left.{ }^{7} 59 \sim 60^{\circ} \mathrm{C}\right)$ および赤外吸収スペクトル，元素分 析により確認した。
分析值
C $63.96 \%$, H $3.90 \%$
$\mathrm{C}_{8} \mathrm{H}_{6} \mathrm{OS}$ としての
計算值
C $64.00 \%, \mathrm{H} 4.00 \%$

蒸留残分をエタノールで再結晶すると淡黄色の結晶が 得られた。これは融点, 赤外吸収スペクトルおよび別途 合成したチオ無水フタール酸との混融点より, チオ無水 フタール酸であることを確認した。

不溶物は炭酸ナトリウム水溶液でよく抽出し, さきの 炭酸ナトリウム水溶液と合わせ塩酸酸性にしてカルボン 酸類を得た。

\section{III. 結果と考 察}

1. 安息香酸 内容 $200 \mathrm{ml}$ のオートクレーブ中で 反応を行なら場合, 水素初圧 $100 \mathrm{~kg} / \mathrm{cm}^{2}$ では水素量は 約 $0.65 \mathrm{~mol}$ で, 加熱かきまぜると $150^{\circ} \mathrm{C}$ 以上ではイオ ウは硫化水素䢻元されるが，過剩の水素も存在してい る。この様な条件下の反応では試料と硫化水素の反応, 試料の水素化分解とが併発する可能性がある。

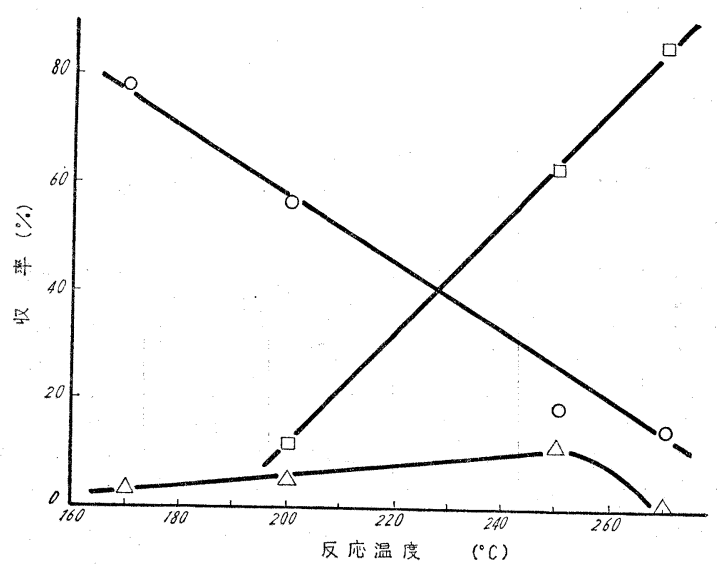

図 1

反応温度の影響

一○一安息香酸, 一 $\square$ ートルエン, 一 $ー$ 一チオール

* 水素初圧 $100 \mathrm{~kg} / \mathrm{cm}^{2}$, 反応時間 140 分 溶媒ンクロへキサン

図 1 亿示寸よらに $170^{\circ} \mathrm{C}$ 付近から $\propto$-トルエンチオー ルの生成が認められるが, $200^{\circ} \mathrm{C}$ で $6 \%, 250^{\circ} \mathrm{C}$ でも $11 \%$ にすぎない。一方トルエンは $200^{\circ} \mathrm{C}$ 以上で生成し，急増 し $275^{\circ} \mathrm{C}$ では未反応試料その他を残さずトルエンになっ

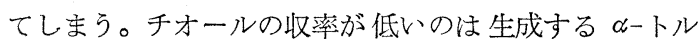
エンチオールの炭素-イオウ結合がベンジル型で， $200^{\circ} \mathrm{C}$ 以下で容易に開裂8 してしまうためである。一方安息香 酸そのものの水素化分解も $200^{\circ} \mathrm{C}$ 以上では容易で, 試料 の水素化による直接トルエンの生成9 も進行するためで 亦る。しかしイオウと水素をほぼ等モル使用した水素初 圧 $50 \mathrm{~kg} / \mathrm{cm}^{2}$ の反応では $250^{\circ} \mathrm{C}$ でも安息香酸が大部分 回収されてチオ酸, チオール, トルエンなどは認められ なかった。したがって硫化水素は安息香酸との直接反応 と考えるよりも触媒上に吸着された試料がまず水素化を らけるが，その中間生成物はさらに水素化されると同時 に触媒上に多量汇存在する硫化水素1 ${ }^{10}$ によって硫化さ

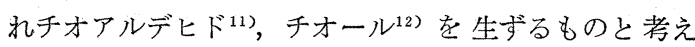
られる。しかしこれらは容易にトルエンへの開裂をして しまうので, チオールの収率は低い。 


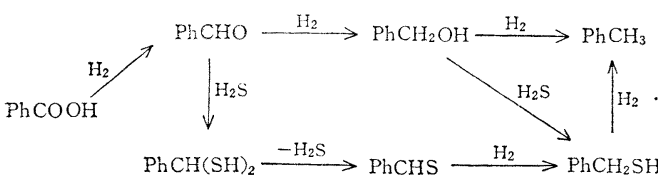

脂肪族カルボン酸の場合，対応するチオールが90\%以 上の収率で得られその他副生物はなく中閒にチオ酸が確 認され，炭化水素は高温において生成しているが1)，こ のことは硫化水素が脂肪酸と直接反応することを示して いる。これは芳香族カルボル酸と脂肪酸の反応性の相異 と共に触媒に対する吸着状態が異なることを示唆するも のである。

表 1 安息香酸の反応におけるイオウ/水素比の影響 反応条件 $; 250^{\circ} \mathrm{C}, 140$ 分, 溶媒シクロへキサン

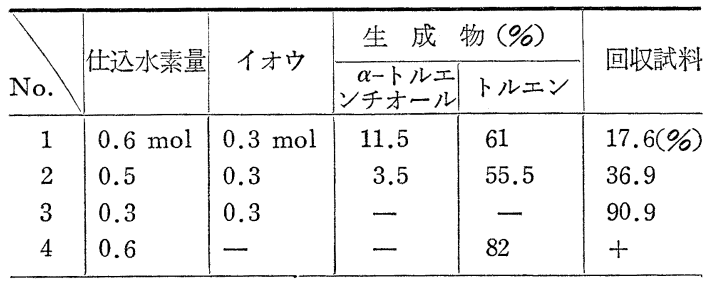

2. 置換安息香酸の反応 オルトまたはパラ位に置 換基を有する安息香酸の還元チオール化を行ない置換基 の影響などについて検討した。

i. 電子供与性基を有する場合 一般に安息香酸にく らべ反応は促進されたが, チオールは確認できなかった。 また脱炭酸生成物が多量生成し安息香酸あるいは電子吸 引性置換基を有する場合にくらべ対称的であった。表 2 に示すように 0 -置換体であるサリチル酸, アントラニ ル酸からはそれぞれ主生成物として，フェノール，アニ リンが得られ，o-クレゾール，o-トルイジンは少量にす ぎなかった。p-アミノ安息香酸の場合もアニリンが主生 成物であったが， $p$-ヒドロキシ安息香酸の場合は $p$-ク レゾールが主生成物で，フェノールは少量であった。ー クレゾール，ーートルイジンは同様条件での水素化反応で は安定であることからフェノール，アニリンの生成は脱 炭酸のためである。

$p$-置換体では脱炭酸は次の順序で容易であった。

$$
\mathrm{NH}_{2}>\mathrm{OH} \gg \mathrm{H}>\mathrm{Cl}
$$

$p$-置換サリチル酸 ${ }^{13)}$ や $p$-または $o$-ヒドロキシ安息 香酸 ${ }^{14)}$ の脱炭酸反応は 置換基の電子供与性の 増加と共 に促進されるが，本反応においても類似の傾向がみとめ られた。しかし 0 -置換体では電子供与性との関係とと もにオルト効果の影響もあって 0 -ヒドロキシ安息香酸 では $p$-体にくらべ脱炭酸生成物が多量に生成した。こ れは 0 -体では隣接カルボキシル基とのキレート環形成
が脱炭酸を促進するためと考えられる。のーメトキシ安息 香酸の場合，主に は はーヒドロキシ安息香酸ではキレート環形成が脱炭酸 を促進するという考えを支持している。

表 2 置換安息香酸の反応 (1) 反応条件; $250^{\circ} \mathrm{C}, 140$ 分, 溶媒シクロヘキサン

\begin{tabular}{|c|c|c|c|}
\hline 置 換 基 & 成 & $(\%)$ & 回取試料(\%) \\
\hline \multirow[t]{2}{*}{$\mathrm{H}$} & $\mathrm{C}_{6} \mathrm{H}_{5} \mathrm{CH}_{2} \mathrm{SH}$ & 11.5 & 17.6 \\
\hline & $\mathrm{C}_{6} \mathrm{H}_{5} \mathrm{CH}_{3}$ & 56.0 & \\
\hline \multirow[t]{2}{*}{$o-\mathrm{OH}$} & $\mathrm{C}_{6} \mathrm{H}_{5} \mathrm{OH}$ & 53.2 & \\
\hline & $o-\mathrm{OHC}_{6} \mathrm{H}_{4} \mathrm{CH}_{3}$ & 28.8 & \\
\hline \multirow[t]{2}{*}{$p-\mathrm{OH}$} & $\mathrm{C}_{6} \mathrm{H}_{5} \mathrm{OH}$ & 21.9 & \\
\hline & $p-\mathrm{OHC}_{6} \mathrm{H}_{4} \mathrm{CH}_{3}$ & 69.6 & \\
\hline$o-\mathrm{CH}_{3} \mathrm{O}$ & $o-\mathrm{CH}_{3} \mathrm{OC}_{6} \mathrm{H}_{4} \mathrm{CH}_{3}$ & 55.0 & 28.0 \\
\hline \multirow[t]{2}{*}{$o-\mathrm{NH}_{2}$} & $\mathrm{C}_{6} \mathrm{H}_{5} \mathrm{NH}_{2}$ & 49.9 & 9.0 \\
\hline & $o-\mathrm{NH}_{2} \mathrm{C}_{6} \mathrm{H}_{4} \mathrm{CH}_{3}$ & 11.6 & \\
\hline \multirow[t]{2}{*}{$p-\mathrm{NH}_{2}$} & $\mathrm{C}_{6} \mathrm{H}_{5} \mathrm{NH}_{2}$ & 74.8 & \\
\hline & $p-\mathrm{NH}_{2} \mathrm{C}_{6} \mathrm{H}_{4} \mathrm{CH}_{3}$ & 7.8 & \\
\hline
\end{tabular}

ii. 電子吸引性基を有する場合 表 3 に示すようにス ルホアミド基やカルボキシル基, 塩素などの電子吸引性 の置換基を有するものは反応性はやや低下したがチオー ルが少量得られ，脱炭酸はほとんどおこらなかった。pスルホアミノ安息香酸は未反応物が多かったのは溶媒に 対する溶解性も影響している。

またp-チオクレゾールの生成はスルホアミド基のメ ルカプト基への還元による ${ }^{15)}$ ものである。テレフター

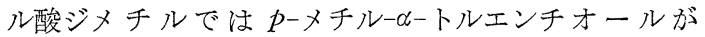
$20 \%$ 生成した。フタール酸, 無水フタール酸は特異で, チオフタリドが主生成物として得られた。以上のように 置換基の影響はその電子供与性と吸引性とでは対称的で あった。すなわち電子供与性基は水素化の反応性を増大 16) し，同時に脱炭酸が促進され，チオールをほとんど 生成しなかった。

表 3 置換安息香酸の反応

(2)

\begin{tabular}{|c|c|c|}
\hline 置 換 基 & 物 (\%) & 回収試料(\%) \\
\hline$p-\mathrm{Cl}$ & $p-\mathrm{ClC}_{6} \mathrm{H}_{4} \mathrm{CH}_{3}$ & 14.4 \\
\hline$p-\mathrm{H}_{2} \mathrm{NSO}_{2}$ & $p-\mathrm{HSC}_{6} \mathrm{H}_{4} \mathrm{CH}_{3} \quad 10.0^{*}$ & 80.0 \\
\hline \multirow[t]{2}{*}{$o-\mathrm{COOH}$} & $\mathrm{C}_{6} \mathrm{H}_{4}\left(\mathrm{COSCH}_{2}\right) \quad 54.4$ & \\
\hline & $\mathrm{C}_{6} \mathrm{H}_{4}(\mathrm{CO}) \mathrm{O} \quad 22.3$ & \\
\hline \multirow{4}{*}{$\begin{array}{l}\text { テレフタタール } \\
\text { 酸ジメチル }\end{array}$} & \multirow{2}{*}{$\begin{array}{ll}p-\mathrm{CH}_{3} \mathrm{C}_{6} \mathrm{H}_{4} \mathrm{CH}_{2} \mathrm{SH} & 20 \\
p-\mathrm{CH}_{3} \mathrm{C}_{6} \mathrm{H}_{4} \mathrm{COOH} & 21.3\end{array}$} & 23.1 \\
\hline & & \\
\hline & $p-\mathrm{HOOCC}_{6} \mathrm{H}_{4} \mathrm{COOH} \quad 18.1$ & \\
\hline & $p-\mathrm{CH}_{3} \mathrm{C}_{6} \mathrm{H}_{4} \mathrm{CH}_{3} \quad++$ & \\
\hline
\end{tabular}

* p - $\mathrm{HSC}_{6} \mathrm{H}_{4} \mathrm{CH}_{2} \mathrm{SH}$ 艺含主

反応条件は表 2 と同じ

3. 無水フタール酸の反応 反忘はもっとも容易で 
$200^{\circ} \mathrm{C}$ では生成物のほとんどがチオフタリドで， $250^{\circ} \mathrm{C}$ ではチオフタリドは一部 0 -キシレンスルフィドまで還 元された。またイオウを $0.4 \mathrm{~mol}$ もちい反応時間を 300 分とした場合, 0 -キシレンスルフィドは増加したが $o-$ キシレンまでの還元は進行しなかった。イオウ $(0.3 \mathrm{~mol})$ に対応量の水素 $(0.33 \mathrm{~mol})$ を用いると生成物の大部分 はチオ無水フタール酸であった。

これらのことから反応はまず酸無水物が硫化水素と反 応してチオ無水フタール酸となり，これがさらに還元さ れチオフタリドとなることがわかった。無水フタール酸 の場合のみイオウ化合物が多量得られたことからイオウ を含む五員環は水素化に安定であると考えられる。

表 4 無水フタール酸の反応

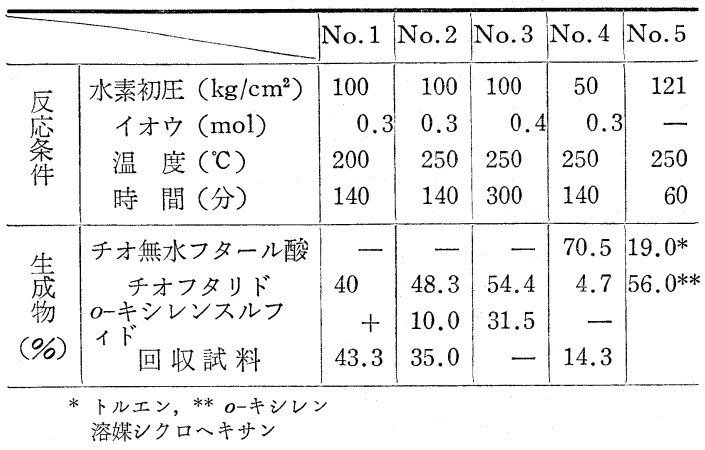

i. 溶媒の影響 水を溶媒としたイオウによる シレンのフタール酸への酸化では中間体としてチオフタ リドが生成し，この反応は可逆的に進行する ${ }^{17)}$ 。そこで 本反応において水を溶媒とした場合とその他の溶媒を用 いた結果を比較した。

表 5 溶媒の影響

反応条件; $250^{\circ} \mathrm{C}, 140$ 分, 水素初圧 $100 \mathrm{~kg} / \mathrm{cm}^{2}$ ， イ オウ $0.3 \mathrm{~mol}$

\begin{tabular}{|c|c|c|c|}
\hline \multirow{2}{*}{ 溶 } & \multicolumn{3}{|c|}{ 反応生 成 物 (\%) } \\
\hline & チオフタリド & $\mid \begin{array}{r}o \text { キシンンス } \\
\text { ルフィド }\end{array}$ & その他 \\
\hline 水 & 76.1 & ++ & 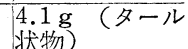 \\
\hline 酢 & 63.3 & ++ & (滎タンチオー \\
\hline トルエン & 52.0 & 16.9 & $\begin{array}{l}\text { ル微量) } \\
15.0 \text { (末応物) }\end{array}$ \\
\hline ジオキサン & 67.3 & 10.0 & 9.0 (末反店物) \\
\hline シクロへキサン & 48.3 & 10.0 & 35.0 (未反応物) \\
\hline
\end{tabular}

水, 酢酸の場合は生成物の大部分がチオフタリドであ った。しかし水溶媒では黒色タール状物, 酢酸溶媒では 酢酸自体が一部チオール化されエタンチオールとなっ た。シクロヘキサン，トルエン，ジオキサンなどの非極 性溶媒を用いるとチオフタリドはさらに水素化されて oーキシレンスルフィドも生成した点が特異である。水
を溶媒として反応温度の影響を調べた。反応は $170^{\circ} \mathrm{C}$ 付近からみられるが, チオ無水フタール酸の段階にとど まらずチオフタリドが得られ，250 C でも スルフィドまでの還元は進まず収率 $80 \%$ でチオフタ リドが得られ，チオフタリド生成には適当な溶媒であっ た。

ii. 反応経路 イオウがまず還元され硫化水素とな り，無水フタール酸に付加し，チオ酸となり脱水閉環し てチオ無水フタール酸になるが，この反応はカルボン酸 との反応にくらべて容易であり, 試料の水素化に優先す る。

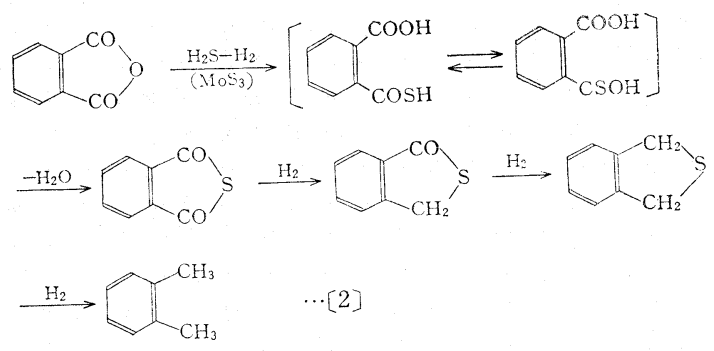

チオ無水フタール酸は水素化され, チオフタリドを生 ずるが，これは水素化に対してかなり安定で ○-キシレ ンスルフィドまで還元するにはより強い条件が必要で, oーキシレンへの開裂は進行しがたい。この間, 硫化水素 による〔3】に示すような無水フタール酸の還元も可能で あるが18，表 4 の No. 4 の実験にみられるよらにほと んど進行しない。

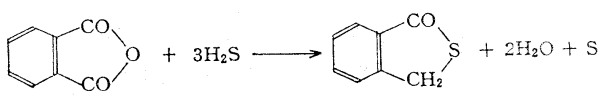

無水フタール酸の三硫化モリブデン触媒による水素化 ではまず開環して o-トルイル酸を生じ，さらにの゙キ レンおよび脱炭酸によるトルエンのみが得られ，フタリ ドあるいは ○-キシレンオキシドは全く認められず，水 素化では無水物環がまず開裂してしまうことが知られて いる9。。れにたいしチオ無水フタール酸では，一般の

表 6 水素化分解 溶媒シクローキサン, 触媒三硫化モリブデン

\begin{tabular}{|c|c|c|c|}
\hline \multicolumn{2}{|c|}{ 試 粼 } & $\begin{array}{l}\text { チオ無水フ } \\
\text { タール酸 }\end{array}$ & チオフタリド \\
\hline 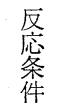 & $\begin{array}{l}\text { 水素初圧 }\left(\mathrm{kg} / \mathrm{cm}^{2}\right) \\
\left.\text { 温 度 ( }{ }^{\circ} \mathrm{C}\right) \\
\text { 時 間 (分) }\end{array}$ & $\begin{array}{r}50 \\
200 \\
100\end{array}$ & $\begin{array}{l}100 \\
250 \\
100\end{array}$ \\
\hline $\begin{array}{l}\text { 生 } \\
\text { 成 } \\
\text { 物 } \\
(\%)\end{array}$ & $\begin{array}{c}\text { チォフタリド } \\
\text { o-キシレンスルフィド } \\
o \text {-キシ シ } \\
\text { 回 収 試 料 }\end{array}$ & $\begin{array}{l}11.2 \\
3.8 \\
- \\
71.8\end{array}$ & $\begin{array}{l}- \\
62.5 \\
15.1 \\
++\end{array}$ \\
\hline
\end{tabular}


スルフィドが水素化反応に対して安定で開裂しがたいの と同様 ${ }^{19)}$ ，この五員環が水素化に対し安定であることが 判った。

本研究を行ならにあたりご指導をいただいた日本大学 理工学部庄野信司教授に感謝いたします。

（日化第 22 年会 (1969) にて一部発表)

\section{文献}

1）板橋国夫，有合化 21.531 (1963)

2) A. Reissert, H. Holle, Ber. 443027 (1911)

3）庄野信司，板橋国夫ら，工化 641357 (1961)

4) 実験化学講座 続 5 (下) p. 1178 (1966) 丸善

5) J.W. Kimball, J. Am. Chem. Soc. 431199 (1921)

6) S.F. Birch, R.A. Dean, E.V. Whitehead, J. Inst. Petrol. 4076 (1954)
7) V. Prey, B. Kerres, H. Berbalk, Monastheft. 91319 (1960)

8）板橋国夫，有合化 17464 (1959)

9）板橋国夫，有合化 17287 (1959)

10) R.L. Wilson, C. Kemball, A.K. Galway, Trans. Faraday Soc. 58583 (1962)

11) E. Campaigen, "Organic Sulfur Compounds" Vol. 1, p. 134 (1961) Pergamon Press.

12）中野紘一，板橋国夫，工化 721029 (1969)

13) A.V. Willi, Trans. Faraday Soc. 55433 (1959)

14) B.R. Brown, D.L. Hammick, A.J.B. Scholefield, J. Chem. Soc. 1950778

15）板橋国夫，有合化 19271 (1961)

16）板橋国夫，亣発表

17) W.G. Toland, J. Org. Chem. 262929 (1961)

18) W.G. Tolond, R.W. Campbell, J. Org. Chem. 283124 (1963)

19) D.J. Martin, J. Org. Chem. 34473 (1969)

\section{一書 評一}

\section{有 機 分子の 構 造}

本書は Illinois 大学の K.L. Rinehart, Jr. 教授によっ て編集されている“Foundations of Modern Organic Chemistry Series”（全18巻）の第 1 巻である。著者 は分子構造，立体配座を中心に多くの研究を発表してい る Allinger 教授夫妻であり，主として大学の学部学生 を対照として平易ではあるが最新の研究結果をとりいれ た有機化学の教科書である。

この本は有機分子の構造が化学反応から全く分離して 取り扱えるという考えに基いて書かれている。原著者は 有機化学を大学院学生に個人的に教えるのと同じ方法, 順序でもっと若い学生にも十分理解させることができる と信じてきた。最初に分子の構造を論じ, 次いで近代的
N.L. Allinger, J. Allinger 著

伊東 溦, 杉山 宏訳

東京化学同人 発行, 137 ページ, 550 円

な手法でどのようにしてその構造が確立されるかを述べ る。理論や物理的手段, 分子の三次元構造に重点を置き 分子の構造や立体化学を理解すれば，化学反応はずっと 容易に理解することができるのである。

内容は原子, 分子構造, 不飽和および環状炭化水素, 官能基をもった化合物, 回転異性, 化学反応中間体, 化 学反応の 8 章からなり, 各章の終りに簡単な問題と, 関 連する代表的な参考書とがあげられているのが特徵であ る。訳は東北大学の伊東教授と Wayne 大学の Allinger 教授のもとに留学されていた杉山博士の手になるもので きわめて流暢で解り易く, 有機化学の入門書として好適 な書物といえよう。

(内丸文彦) 